\title{
Imipenem Resistance Gram-Negative Bacilli Isolated from Patients of a Tertiary Care Hospital in Dhaka, Bangladesh
}

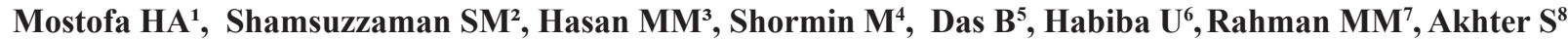

\begin{abstract}
Conflict of Interest: None

Received: 21.03 .2020

Accepted: 05.04 .2020

www.banglajol.info/index.php/JSSMC

Introduction: The emergence of antibiotics resistance bacteria is a persistent global problem affecting public health. The occurrence and widespread resistance to Imipenem among hospital bacterial isolates can constitute a significant threat to chemotherapy.
\end{abstract}

Objectives: This cross-sectional study aimed to investigate the imipenem resistant pattern among gram-negative bacilli isolated from different samples in Dhaka medical college hospital.

Methods: A total of 300 samples (wound swab, urine, endotracheal aspirate, blood, and sputum) were collected from July 2015 to June 2016. Two hundred four gram-negative bacilli were isolated and tested for resistance to imipenem by the disc diffusion method.

Results: Among 204-gram negative bacilli, 39.21\% imipenem resistance was detected by the Disc Diffusion method. $14.7 \%$ imipenem resistance gram-negative bacilli were from wound

Key Words:

Antibiotic resistance, Imipenem, Gram-negative bacilli. swab. $83.33 \%$ of Acinetobacter baumannii were Imipenem resistant.

Conclusions: Imipenem resistance is widespread among gram-negative bacilli isolated from human infections. Imipenem resistance (39.21\%) found in the study is quite worrisome.

[J Shaheed Suhrawardy Med Coll 2020; 12(1): 3-5] DOI: https://doi.org/10.3329/jssmc.v12i1.51610

\section{Introduction}

Resistance patterns among bacterial pathogens are one of the most critical problems in hospitals that may vary widely from country to country, and its-related mortality and morbidity remain extremely high. ${ }^{1}$ The rate of bacterial resistance is markedly higher in many developing countries, probably because of a lack of supervision, poor

1. Dr. Hasbi Ara Mostofa, Assistant professor, Department of Microbiology, Shaheed Suhrawardy Medical College, Dhaka.

2. Dr. S. M. Shamsuzzaman, Professor and Head, Department of Microbiology, Dhaka Medical College, Dhaka.

3. Dr. Md. Maniul Hasan, Assistant professor, Department of Surgery, Shaheed Suhrawardy Medical College, Dhaka.

4. Dr. Moonmoon Shormin, Assistant professor, Department of Microbiology, Shaheed Monsur Ali Medical College, Dhaka.

5. Dr.Bithi Das, Assistant professor, Department of Microbiology, Shaheed Suhrawardy Medical College, Dhaka

6. Dr.Umme Habiba, Assistant professor, Department of Microbiology, Shaheed Suhrawardy Medical College, Dhaka.

7. Prof. Md. Mustafizur Rahman, Professor and Head, Department of Surgery, Shaheed Suhrawardy Medical College, Dhaka

8. Dr. Shakila Akhter, Assistant Professor, Department of Pharmacology, National Institute of Cardiovascular Disease (NICVD), Dhaka

Correspondence to: Dr. Hasbi Ara Mostofa, Assistant professor, Department of Microbiology, Shaheed Suhrawardy Medical College, Dhaka. Mobile: +8801717921581, E-mail -hasbiaramostofa@gmail.com infection prevention practices, inappropriate use of limited resources, and overcrowding of hospitals. ${ }^{2,3}$ It seems that the overuse of effective antibiotics is also a potent cause of bacterial resistance, especially in these counties. Imipenem has retained in vitro activities that are superior to those of other antimicrobials. In many centers, it has been selected as the first choice for patients with infections caused by gram-positive and gram-negative bacteria. ${ }^{4-9}$ Imipenem remains the most active drug; recently, Imipenem retained activity against $100 \%$ of strains, and in some previous reports, the only active drug was Imipenem. ${ }^{10}$ However, recent analyses of hospital outbreaks have documented the spread of resistance to this antibiotic, and it is currently a significant problem among gram-negative bacteria.

In the present study, we tried to describe the rate of gramnegative isolates resistance to Imipenem is an antibiotic that is widely used in our country.

\section{Materials and methods}

A total of 300 samples (wound swab, urine, endotracheal aspirate, blood, and sputum) were collected from July 2015 to June 2016 in Dhaka Medical College Hospital in a crosssectional study. All the wound swab, urine, pus, and 
endotracheal aspirate samples were inoculated in blood agar and MacConkey agar media and incubated at 37p C aerobically for 24 hours.

Incubated plates were then examined for the presence of colonies of bacteria. Primary blood culture was done in Trypticase soya broth; then, the subculture was done on blood agar and MacConkey agar media. 204-gram negative bacilli were isolated.

Susceptibility to Imipenem of all isolates was done by Kirby Bauer modified disk diffusion technique using Muller Hinton agar plates, and zones of inhibition were interpreted according to CLSI guidelines (CLSI, 2015).

Antibiotic discs imipenem $(10 \mu \mathrm{g})$ was used. The examined clear zone of inhibition around the disc on the test organisms were interpreted as resistant and sensitive.

All strains were tested for antibiotic susceptibility by Disk Diffusion and were designated for Imipenem as susceptible if the inhibition zone diameter was $\geq 22 \mathrm{~mm}$, intermediate if the inhibition zone diameter was $19-21 \mathrm{~mm}$, and resistant if the inhibition zone diameter was $\leq 18 \mathrm{~mm}$, as recommended by Clinical and Laboratory Standard Institute (CLSI) (2015). ${ }^{11}$

\section{Result}

Of the total 300 samples, 150 were wound swabs, 65 were urine, 40 were endotracheal aspirates, 30 were blood, and 15 were sputum. From these 300 samples, 204 (68\%) gram-negative bacteria were isolated (Table 1). In Table 2, Out of 204 isolated gram-negative bacteria, 80 (39.21\%) imipenem resistant strains were detected. Of which, 30 (14.7\%) from wound swab, 6 (2.94\%) from urine, 37 (18.13\%) from ETA, 5 (2.45\%) from blood and $2(0.98 \%)$ from sputum samples were detected. Twelve $(27.9 \%)$ of the 43 Esch.coli, 9 (34.61\%) of the $26 \mathrm{~K}$. pneumoniae, 4 $(30.76 \%)$ of the $13 \mathrm{~K}$. oxytoca, $6(37.5 \%)$ of the 16 Citrobacter freundii, $2(28.57 \%)$ of the 7 Proteus vulgaris, one (16.67\%) of the 6 Proteus mirabilis, $2(20 \%)$ of the 10 Enterobacter aerogenes, 20 (83.33\%) of the 24 Acinetobacter baumannii, 24 (46.15\%) of the 52 Pseudomonas aeruginosa were Imipenem resistant. None of the Citrobacter koseri and Salmonella spp. were Imipenem resistant.

\section{Table I}

Isolated gram negative bacteria from different samples $(N=300)$.

Type of samples Number Isolated gram negative of samples bacteria $\mathrm{n}(\%)$

\begin{tabular}{lcc}
\hline Wound swab & 150 & $121(80.66)$ \\
Urine & 65 & $33(50.80)$ \\
Endotracheal aspirate & 40 & $35(87.50)$ \\
Blood & 30 & $9(30.00)$ \\
Sputum & 15 & $6(40.00)$ \\
\hline Total & 300 & $204(68.00)$ \\
\hline
\end{tabular}

$\mathrm{N}=$ Total number of bacteria. $\mathrm{n}=$ Total number of positive cases.

\section{Table-II}

\begin{tabular}{|c|c|c|c|c|c|c|}
\hline \multicolumn{7}{|c|}{$\begin{array}{l}\text { Imipenem resistant organisms among different species of isolat } \\
\text { samples. }(N=204)\end{array}$} \\
\hline Organism & $\begin{array}{c}\text { Wound swab } \\
\text { n (\%) }\end{array}$ & $\begin{array}{l}\text { Urine } \\
\mathrm{n}(\%)\end{array}$ & $\begin{array}{c}\text { ETA } \\
\mathrm{n}(\%)\end{array}$ & $\begin{array}{l}\text { Blood } \\
\mathrm{n}(\%)\end{array}$ & $\begin{array}{l}\text { Sputum } \\
\mathrm{n}(\%)\end{array}$ & $\begin{array}{l}\text { Total } \\
\mathrm{n}(\%)\end{array}$ \\
\hline Esch. $\operatorname{coli}(\mathrm{N}=43)$ & $5(11.62)$ & $2(4.26)$ & $3(6.97)$ & $2(4.65)$ & $0(0.00)$ & $12(27.90)$ \\
\hline K.pneumoniae $(\mathrm{N}=26)$ & $2(7.60)$ & $1(3.84)$ & $3(11.53)$ & $2(7.69)$ & $1(3.80)$ & $9(34.61)$ \\
\hline$K . \operatorname{oxytoca}(\mathrm{N}=13)$ & $2(15.30)$ & $0(0.00)$ & $1(7.69)$ & $0(0.00)$ & $1(7.70)$ & $4(30.76)$ \\
\hline C. freundii $(\mathrm{N}=16)$ & $2(12.50)$ & $1(6.25)$ & $3(18.75)$ & $0(0.00)$ & $0(0.00)$ & $6(37.50)$ \\
\hline C. $\operatorname{koseri}(\mathrm{N}=5)$ & $0(0.00)$ & $0(0.00)$ & $0(0.00)$ & $0(0.00)$ & $0(0.00)$ & $0(0.00)$ \\
\hline P. vulgaris $(\mathrm{N}=7)$ & $2(28.57)$ & $0(0.00)$ & $0(0.00)$ & $0(0.00)$ & $0(0.00)$ & $2(28.57)$ \\
\hline P. mirabilis $(\mathrm{N}=6)$ & $1(16.66)$ & $0(0.00)$ & $0(0.00)$ & $0(0.00)$ & $0(0.00)$ & $1(16.67)$ \\
\hline E.aerogenes $(\mathrm{N}=10)$ & $1(10.00)$ & $0(0.00)$ & $1(10.00)$ & $0(0.00)$ & $0(0.00)$ & $2(20.00)$ \\
\hline Salmonella spp. $(\mathrm{N}=2)$ & $0(0.00)$ & $0(0.00)$ & $0(0.00)$ & $0(0.00)$ & $0(0.00)$ & $0(0.00)$ \\
\hline A.baumannii $(\mathrm{N}=24)$ & $3(12.50)$ & $0(0.00)$ & $16(66.67)$ & $1(4.16)$ & $0(0.00)$ & $20(83.33)$ \\
\hline P.aeruginosa $(\mathrm{N}=52)$ & $12(23.07)$ & $2(3.85)$ & $10(19.23)$ & $0(0.00)$ & $0(0.00)$ & $24(46.15)$ \\
\hline Total & $30(14.70)$ & $6(2.94)$ & $37(18.13)$ & $5(2.45)$ & $2(0.98)$ & $80(39.21)$ \\
\hline
\end{tabular}

$\mathrm{N}=$ Total number of bacteria $\mathrm{n}=$ Total number of positive case 


\section{Discussion}

Infection due to gram-negative bacteria is a leading cause of morbidity and mortality worldwide (Giske et al., 2008). ${ }^{12}$ In the present study, 204 (68\%) gram-negative bacteria were isolated from 300 wound swabs, urine, ETA, blood samples, and sputum (Table 1).

In the present study, 80 (39.21\%) imipenem resistant organisms were identified among 204-gram negative bacteria. Of which, 37 (18.13\%) from ETA, 30 (14.7\%) from wound swab, 6 (2.94\%) from urine, 5 (2.45\%) from blood and 2 (0.98\%) from sputum samples (Table2). A previous study by Farzana (2013) (13) in DMCH found that $28.77 \%$ of gram-negative organisms isolated from wounds were resistant to Imipenem. In another study, Afrin (2013) (14) in DMCH found that $47.42 \%$ of gram-negative bacteria isolated from ETA were resistant to Imipenem. The reasons behind the higher isolation rate of Imipenem resistant organisms in Afrin (2013) study might be because all the samples of Afrin (2013) were collected from ICU. All were ETA, but in the present study, samples were collected from both general wards and ICU, which were wound swab, urine, ETA, blood, and sputum. In another study in DMCH by Khatun (2014) (15), 18.07\% from ETA, $10.5 \%$ from wound swab, $3.36 \%$ from urine, and $3.36 \%$ from blood samples were resistant to Imipenem. In the present study, the most common $66.67 \%$ Imipenem resistant organism isolated from ETA was Acinetobacter baumannii; the findings were close to Khatun (2014) data $70.96 \%$ Acinetobacter baumannii were resistant to Imipenem.

\section{Conclusion:}

Imipenem is currently associated with nosocomial isolates; one of the most worrisome concerns is the spread of these Imipenem resistant strains in the community. This study represents a significant threat to public health, warranting increased efforts towards detection and infection control strategies.

\section{References}

1. Stratchounski LS, Kozlov RS, Rechedko GK,Stetsiouk OU, Chavrikova EP; Russian NPRS study group (1998). Antimicrobial resistance patterns among aerobic gram-negative bacilli isolated from patients in intensive care units: results of a multicenter study in Russia. Clin Microbiol Infect, 4:497-507.

2. Juan-Torres A, Harbarth S (2007). Prevention of primary bacteremia. Int J Antimicro Agents, 30 Suppl 1: S80-7.

3. Bassetti M, Melica G, Cenderello G, Rosso R, Di Biagio A, Bassetti D (2002). Gram-positive bacterial resistance. A challenge for the next millennium. Panminerva Med, 44(3):179-84.

4. Boroumand MA, Esfahanifard P, Saadat S, Sheihkvatan M, Hekmatyazdi S, Saremi M, et al. (2007). A report of Pseudomonas aeruginosa antibiotic resistance from a multicenter study in Iran. Indian J Med Microbiol, 25(4): 435-6.

5. Bataine HA, Alrashed KM (2007). Resistance gram-negative bacilli and antibiotic consumption in Zarqa, Jordan. Pak $J$ MedSci, 23(1): 59-63

6. Shahcheraghi F, Nikbin VS, Shooraj F (2008).PCR detection of PER \&VEB \&SHV and TEM â-lactamases in multidrug-resistant $P$. aeruginosa isolated from wound infections in two hospitals of Tehran. Iranian J Med Microbial, 4(1): 21-7.

7. Akhi MT, Farzaneh F, Oskouei M (2009).Study of enterococcal susceptibility patterns isolated from clinical specimens in Tabriz,Iran. Pak Med, 25(2): 211-6.

8. Shahcheraghi F, Noveri H, Nasiri S (2007).Detection of bla TEM $\&$ bla SHV genes among clinical isolates of Escherichia coli from Tehran hospitals. Iranian J Med Microbial, 1(3): 1-8.

9. Feizabadi MM, Etemadi G, Yadegarinia D, Rahmati M, Shabanpoor S, Bokaei S. Antibiotic- resistance patterns and frequency of extended-spectrum beta-lactamase-producing isolates of Klebsiella pneumoniae in Tehran. Med Sci Monit, 12(11): BR362-65.

10. Andrews HJ (1986). Acinetobacter bacteriocin typing. J Hosp Infect, 7(2): 169-75.

11. Clinical and Laboratory Standard Institute (CLSI). Performance standards for antimicrobial susceptibility testing: Nineteenth Informational Supplement. CLSI document M100-S19. Wayne, PA: CLSI; 2015.

12. Gasink LB, Edelstein PH, Lautenbach E, Fishman NO. Risk factors and clinical impact of Klebsiella pneumoniae carbapenemase-producing K. pneumoniae. Infect Control Hosp Epidemiol, 2009; 30 (12): 1180-85.

13. Farzana R, Shamsuzzaman SM, Mamun KZ, Shears P. Antimicrobial susceptibility pattern of extended spectrum betalactamase producing gram-negative bacteria isolated from wound and urine in a tertiary care hospital, Dhaka City, Bangladesh. Southeast Asian J Trop Med Public Health, 2013; 44 (1): 96-03.

14. Afrin S. Bacterial causes of ventilator associated respiratory tract infection. [M. Phill thesis] Dhaka: DMC; 2013: pp.52-82.

15. Khatun R. Phenotype and genotype of ESBL and Carbapenemase producing bacterial isolates at DMCH. [M. Phil thesis]. DMC, 2014. 